\title{
MEKÂNIN TÜKETIMİ BAĞLAMINDA KENT IRKÇILARI (FALCILARI)
}

\section{Cevdet Avci*}

\section{Anahtar Kelimeler}

Özet

APA'ya göre alıntılama: Avcı, C. (2020). Mekânın tüketimi bağlamında kent ırkçıları (falcıları). Uluslararası Dil, Ĕ̆itim ve Sosyal Bilimlerde Güncel Yaklaşımlar Dergisi (CALESS), 2(1), 372-394.

Cited as (APA): Avc1, C. (2020). The urban fortune-tellers in the context of consumption. International Journal of Current Approaches in Language, Education and Social Sciences (CALESS), 2(1), 372-394.

\footnotetext{
* Dr. Öğr. Üyesi, Gaziantep Üniversitesi, Fen Edebiyat Fakültesi, Türk Dili ve Edebiyatı Bölümü, Gaziantep, Türkiye, e-posta cevdetavci@outlook.com.tr
} 


\section{THE URBAN FORTUNE-TELLERS IN THE CONTEXT OF CONSUMPTION}

Keywords
Abstract
Article Info

Received: 16.05 .2020

Accepted: 23.06 .2020

Online Published: 28.06.2020
Changing forms of production consumption in the historical process have affected the cultural lifestyles of societies. Urbanization that emerged with industrialization; it has provided the reproduction of cultural structures, places and tradition. In this context, the coffeehouse institution, which has been shaped around the coffee drink, has become a social sharing area. West moved to this institution, with the impact of globalization turning into cafes and cultural industries have become widespread in Turkey. The cafe, which is an example of urban space, is an area where cultural contents are consumed along with various beverages. Fortune-telling culture, which is one of the old belief systems, or an important place in social life, has been moved to cafes in the urban environment. Looking at fortune-telling at the cafe is an example of the consumption style of culture along with the space. In the article, the understanding of space, which emerged in line with the new social needs in the urban environment, is discussed within the framework of the transformation from coffee shop to cafe. Fortune telling, which takes place in traditional culture in the new consumption environment, has taken place in the daily life of the urban and literate society. In this context, firstly, a literature review was made on the subject, the data were collected by document analysis method and the information received from the source people by questionnaire and interview method was used to verify the determined data. Fortune telling culture, which is a means of understanding the life of people and their future, since primitive times, continues in cafes, which is the consumption style of urban life style. Although fortune-telling culture has been brought to digital environment; Satisfaction and therapy effect provided by verbal communication in cafes will ensure the continuity of culture in real places.

\section{Giriş}

\section{"Fala inanmadık falsız da kalmadık"}

19. yüzyılda Avrupa'da başlayan Sanayi Devriminin etkisiyle oluşan yeni ekonomik sistem, dünyanın geri kalanında da sosyo-kültürel hayatı etkiler. Toprağa bağl1 yaşam biçiminin değişmesi, kentleşmenin getirdiği yeni mekân ve zaman alg1sı bu süreçte ortaya çıkar. Kapitalizmin tüketim ekonomisine dayalı bir kitle kültürü yaratma baskısı, ulaşım ve iletişim imkânlarının geliştirilmesiyle birlikte, toplumların kültürel hayatına yansır. Böylece kültürün mekân ve gelenek boyutları yeniden kurgulanır. Kentleşme süreçleriyle birlikte yeni kültürel üretim-tüketim tarzları ortaya çıkar. Moda ve popüler kültür kavramlarının ön plana çıktığı bu süreçte, medyanın yazıl1-işitsel-görsel unsurlarının önemli etkisi görülür. İnsanın psiko-sosyal, kültürel ve estetik ihtiyaçları, yeni yaşam biçimi içerisinde tüketim yerleri ve içerikleriyle karşılanır. Türkiye'deki geç sanayileşme-kentleşme süreçleri bu durumun daha 
kompleks ve hızlı işlemesine neden olur. Kentli insan, mekânla birlikte geleneğin de tüketildiği kültürel ortamlarla tanışır.

$\mathrm{Bu}$ çalışmada $1 \mathrm{rkçıllı/falcılık} \mathrm{geleneğinin} \mathrm{yeni} \mathrm{yaşam} \mathrm{biçimi} \mathrm{içerisinde} \mathrm{ortaya}$ çıkan mekânlara taşınması ve kentli insanın geleneği tüketim örneğine dönüşmesi incelenecektir. Bu çerçevede öncelikle literatür taraması yapılmış, veriler doküman analizi tekniğiyle toplanmıştır. Tespit edilen verilerin doğrulanmasında kaynak kişilerden anket ve görüşme yöntemiyle elde edilen bilgiler kullanılmıştır. Kaynak kişiler Gaziantep'teki kafelerde aktif olarak falcllık yapan falcılardan seçilmiştir. Fala bakılan kafelerin isimleri çalışmada kullanılmamıştır. Aktif olarak kafelerde falcılık yapan on bir falcıdan üçü, isminin çalışmada kullanılmasını istememiştir. Sanayi, ticaret ve tarım şehri olan Gaziantep, aynı zamanda dört üniversitenin bulunduğu, genç nüfusun fazla olduğu bir büyükşehirdir. Bu açıdan Gaziantep kentleşmenin yarattığı geleneğin yeni tüketim tarzları ve mekânlarına önemli bir örneklem teşkil eder. Çalışmada Türkiye'nin diğer kentlerindeki benzer tüketim biçimleri yazılı ve elektronik kaynaklar üzerinden taranmıştır.

\section{Kent, Mekân ve Tüketim}

Bir bilim dalı olarak folklor/halk bilimi ortaya çıktığı 19. yüzyıldan bu yana, araştırma alanlarını ve yöntemlerini sürekli güncellenmiştir. Avrupa'da Sanayi Devrimi sonrası ortaya çıkan hızlı kentleşme, yeni meslek gruplarının ortaya çıkışı, 20. yüzyıldaki ulaşım ve iletişim alanlarındaki gelişmeler, bu güncellemenin sebepleri arasındadır. Kültürün değişen üretim-tüketim tarzlarıyla birlikte ortaya çıkan yeni toplumsal yapılar, kültürel içerikler ile kültürün paylaşım ve dolaşım alanları halk biliminin araştırma sahasını genişletmiştir. Halk ve halk bilgisi kavramlarının güncellendiği bu süreçte halk bilimi, disiplinlerarası çalışma yöntemlerini benimsemiştir. Sözlü, yazılı ve elektronik kültür ortamları halk bilgisi ürünlerinin yaratım, aktarım ve tüketim yerleri olarak halk bilimcinin araştırma sahası olurken, kent folkloru, meslek folkloru, beden folkloru, internet folkloru gibi pek çok alt başlık halk biliminin inceleme alanına girmiştir (Dundes, 1998: 139-157; Ekici, 2000: 2-8; Çobanoğlu, 2005: 19-22; Ersoy, 2012: 5-13). İki asırlık hızlı değişim süreci, halk bilimi çalışmalarının ürün, üretim, üretici ve mekân odaklı şekillenmesini sağlamıştır. M. Öcal Oğuz, kentleşme, kültür endüstrisi ve kitle iletişim teknolojileri karşısında halk bilgisi ürününü yaşatarak korumanın zor olduğuna dikkat çekerek halk biliminde üretimin ve kültürel belleğin korunduğu mekân odaklı çalışmaların önemine vurgu yapar (Oğuz, 2007: 31-33). Bu kapsamda kentleşme süreçleriyle birlikte geleneksel kültürel mekânlar dönüşerek kent ortamında yeniden üretilir.

Kentlerin oluşumu ve gelişiminde temel etkenlerden birisi ekonomik üretimtüketim biçimidir. Tarım ekonomisinin ortaya çıkması ve toprağa bağlı yaşam biçimi, büyük insan gruplarının bir arada yaşamasını sağlamıştır. Benzer şekilde modern şehirler de Mübeccel B. Kıray'ın ifadesiyle, "toplumun yeni üretim biçimlerinin bir parçası" (Kıray, 1998: 9) olarak şekillenmektedir. Bu süreçte kentleri oluşturan iki 
temel dinamiğin "mekân ve demografi" olduğunu söyleyen Morrey Bookchin, kent ve anakent kavramlarını birbirinden ayırır. Ona göre anakent, "sınırlarını ve özgünlüklerini yitirecek ölçüde büyümüş" alanlarken kent ise; "toplumsal potansiyellerin, bunların gelişim evrelerinin, geleneklerin, kültürün ve yerleşik bir insan topluluğuna ait özelliklerin birikimci gelişimini ya da diyalektiğini" içeren bir yapıdır (Bookchin, 1999: 17). Diğer taraftan 19. yüzyıldan itibaren Avrupa'da ortaya çıkan kentleşme anlayışı farklı kültür kümelerini tanımlayacak biçimde "kentsel" ve "kırsal" alan kavramlarını yaratır ve ikisi arasındaki sınırları belirginleştirir (Holton, 1999: 151).

David Harvey, "Kent Deneyimi" (2016) adlı çalışmasında kenti oluşturan kuvvetleri "para, mekân ve zaman" (Harvey, 2016: 233) olarak tanımlar. Kapitalizm bu üç parametreyi kullanarak oluşturduğu kentte, kendi tüketici kitlesini de üretir. Bu kitlenin ekonomik yapısı belirlenmiş ve zaman-mekân algısı, yeni tarz tüketim kültürüne uyumlu hale getirilmiştir. Endüstri çağında kitlelerin kentlerde bir araya toplanması, homojen tüketim pazarlarının oluşmasına neden olur. Sanayileşen toplum, üretilen malların paraya dönüştürülmesini sağlayan tüketim ağına dönüşür. Kapitalizmin kültürü "kendi kendini tüketen tutkuyu" (Sennett, 2011: 90) insanlara sunar.

İnsanın hayatta kalmak için ihtiyacı olanı aramayla başlayan tüketim anlayışı, "tüketimin evrimiyle" (Miller, 2012), Jean Baudrillard, “Tüketim Toplumu” (2013) çalışmasında olgunun geldiği noktayı ifade etmek için kullandığı, "tüketimin tüketimine” dönüşmüştür. Baudrillard'a göre, “Tüketim bir söylendir. Yani tüketim çağdaş toplumun kendisi üstüne bir söz, toplumumuzun kendisiyle konuşma tarzıdır." (Baudrillard, 2013: 233). Toplumun kentte kitleselleşerek tüketim organizmasına dönüşmesi yaşanan ekonomik ve siyasal süreçler yakından ilgilidir. "Tüketim, modernizm sonu kapitalizminin ya da "post-modern" kapitalizmin tipik özelliklerini sergileyen bir süreç haline gelmiştir." (Bocock, 1997: 113).

Kapitalizmin yeni yerleşim tipi ve tüketim kültürünü dayatmacı yaklaşımları karşısında toplum tamamen edilgen değildir. İnsan, bir taraftan yeni yaşam ve biçimi ekonomik sistemlere entegre olurken bir taraftan da yaşadığı çevreyi kültürel beklentilerine göre şekillendirmenin arayışına girmiştir. Kentlerde "insanların ayakları altında işleyecekleri toprakların olmayışı" (Sennett, 2011: 57), toprağa bağlı değerler sistemi ve kültürel belleğin yersiz kalmasına neden olmuştur. Bu çerçevede kent ve kır arasındaki süreklilik, şehrin metabolizması açısından önemli bir unsur haline gelmiştir. Şehri bir arada tutan kültürel değer ve idealler, kuvvetini bu süreklilikten alır (Harvey, 2013: 206).

Bener ekonomik sistemler, kentler arasındaki yapısal farklılıkları azaltııştır. Özellikle endüstri çağının başlangıç dönemlerinde "sosyal grupların yaşam alanları arasındaki farklar bugün için daha esnetilmiş” (Bal, 2006: 53) ve kentlerde bütün sosyal kesimlerin bir arada olabileceği müşterek alanlara dönüşmüştür. Geleneksel yaşam biçiminin değişmesiyle kültürel "hafıza mekânlarından" (Nora, 2006) kopan insan, 
kent hayatında yeni bellek ortamları yaratır. Böylece gündelik hayatta, eğlence, zaman geçirme, sosyal paylaşım ve aktarım ortamları olarak "kentli mekân" (Aytaç, 2007: 200) devreye girer. Fakat bu mekân biçimi, geleneksel çevredeki belleğe dayalı kültürel yapılardan farklıdır. Kentli mekân, yeni ekonomik sistemin ortaya çıkardı̆̆ı "kültür endüstrisi" (Adorno, 2011) tarafından dizayn edilmiş yeni toplumsal hayatın üretildiği alandır. Ömer Aytaç kent mekânlarını şu şekilde analiz eder:

“Bunların her biri, kendi çapında, dil, söylem, temsil, kimlik, statü, imaj, prestij, simge ve gösterge üretir, bunları dolaşıma açar, bunlar üzerinden belli bir kültürel form, alt kültür, mekânsal cemaat vs. inşa eder. Bu yönleriyle, her bir mekân temsil ettiği kodlar gereği, kent aurası içinde, bir hiyerarşi yaratır, bu hiyerarşi kendilerine yönelen müdavimlerle birlikte yeni bileşimlere kap1 aralar. Bu yönleriyle, mekânlar, ürettikleri ve yaslandıkları imgeler/semboller üzerinden aidiyet matrisleri, mekânsal ayrışma/dışlama mekanizmaları, grupsal özdeşlikler ve kişisel temsiliyetler inşa eder." (Aytaç, 2007: 222).

Kentli insan geleneksel kültür yapısından kopuşa karşı bu yeni mekân içerisinde kendini var etme arayışına girer. Mekân ve kentin ideal formunda "ütopya, ideal, huzur, mutluluk, ayrıcalıklı yaşam, düşsel hayat gibi kavramlar da bu yeni mekânların süslenmesi için devreye sokulmaktadır" (Alver, 2009: 151). Yeni mekânın oluşturulması, kentli tüketim toplumunun iş, zaman ve mekân kategorisinden bağımsız değildir. Toprağa bağlı yaşam biçiminde iş, gündelik zamanı kapsayan ve hayatın çerçevesini oluştururken sanayi toplumunun iş hayatı günün belirli saat aralığını kapsar. Böylece iş, zaman ve mekân bir ölçüde birbirinden ayrılmış olur. Bu durum kentli mekân oluşturma politikalarını, "boş zaman sorunsalı" problemini çözmeye yöneltir. Oluşan yeni mekân bunun ötesine geçer ve anlamlar, gelenekler ve bağlılıklar yer kavramı etrafında oluşur, ekonomik ve siyasi örgütlenme biçimleri, iktidar ve bağımlılık, mahaller (kentler, bölgeler, uluslar) arasındaki ilişkilerin içerisinde yer alır." (Morley, Robins, 1997: 108).

Mekânla insan arasındaki ilişki döngüseldir. İnsanın doğal ya da üretilmiş ihtiyaçlarına cevap veren mekân, kent insanının gündelik hayatının merkezindedir. Çünkü kentler insanı doğadan kısmen kopartarak mekânlarla yaşatır. Bu açıdan "mekân ve özne" arasındaki canlı ilişki, ortak yaşama dair "diyalojik bir sürece" dönüşür (Ertürk, 2013: 90). Bu bağlamda Henri Lefebvre Mekânın Üretimi (2014) adlı çalışmasında; "Tarihin ürünü olan mekân, maddi planlamanın, mali planlamanın ve mekân-zaman planlamasının buluştuğu yerdir." (Lefebvre, 2014: 15) tespitini yapar.

Kentli mekân zaman içerisinde toplumsal bellek birikimi de sağlayabilir. Belleğe dayalı mekânsal tüketim biçimi, kentlerde yaşayan insan için önemlidir (Groh, 2016: 193). Diğer taraftan bu yeni mekân tüketim olgusunun ortasındadır. John Urry, kentteki mekân için daha keskin bir ifade kullanır ve "tüketim için var olan, simüle edilmiş toplumsal kimlik duygusu sunmayan yerler" yorumunu yapar. Yine ona göre kentteki "yer imajları ürün ve hizmetlerin simgesel yerleşiminde rutin olarak kullanılmaktadır. Özel yerler, özel tüketim türlerini gerektirir. Belirli ürünler ve 
hizmetler sadece özel bir yeri ziyaret ederek elde edilebilir." (Urry, 1999: 37, 47). Dolayısıyla, "Tüketim kavramı, toplumsal kesimleri belirleyici sosyo-kültürel bir faaliyet ya da faaliyetler bütünüdür." (Özdemir, 2012: 33). Kentli mekân bu faaliyetlerin gerçekleştiği sosyo-kültürel ve ekonomik bir pazar alanına dönüşür.

\section{Mekânın Dönüşümü Kahvehaneden Kafeye}

Avrupa'da 19. yüzyılda başlayan sosyo-ekonomik ve kültürel değişmeler, geleneksel toplumsal yapılardaki çoğulculuğun yerine kent hayatında bireyselliğin ön plana çıkmasına neden olmuştur. Bu durum benzer süreçleri yaşayan diğer toplumlara da yansımıştır. Modernizmin yarattığı sorunlardan birisi olarak görülen bu durum, kentte bunalan insanların çıkmazlarından birisi olmuştur. Bunun üzerine kentteki insanın çabası, "bireyin, bunaltıcı toplumsal güçler, tarihsel miras, dışsal kültür ve hayal tekniği karşısında kendi varoluşunun özerklik ve bireyselliğini koruma talebi" üzerine şekillenir (Simmel, 2009: 317). Bu durumda kent hayatındaki mekânlar ve geleneksel kültürün imlerini taşıyan içerikler, önemli sığınaklara dönüşür. Kentte ortaya çıkan yapılar ve tüketim tarzları "kültür ekonomisi" (Özdemir, 2012) tarafından yönlendirilse de kentli insanın gündelik hayatında kültürel boyut kazanır. Kahvehanenin kafeye dönüşüm sürecini bu geri plan üzerinde ele alınabilir.

Kahvehanenin sosyal paylaşım ve aktarım alanı olarak ortaya çıkmasında içme kültürünün önemli rolü vardır. Kentleşme süreçlerinde her toplumdaki içme kültürü, yeni mekânların ortaya çıkmasını sağlamıştır. Kültür ve coğrafyaya bağlı olarak değişen içme davranışlarının ortaya çıkardı̆̆ı sosyalleşme mekânları pek çok toplumda görülür. “Almanların birahaneleri, İngilizlerin 'pub'ları, Fransızların 'cafe'leri" (Çağlayan, 2012: 96) gibi Anadolu'da dört asırlık geçmişi olan kahvehaneler de kahve içme davranışının sonucu ortaya çıkmış sosyal paylaşım alanlarıdır. Kahvehaneyi Anadolu'nun ilk kamusal mekânı olarak tanımlayan Savaş Çağlayan'ın ifadesiyle kahve 15. yüzyılda İslâm ülkelerinde yaygınlaşmaya başlamıştır. "Genel bir kanıya göre kahve bitkisinin ve meyvesinin kullanımı Etiyopya'dan dünyaya yayılmıştır. İslam dünyasına yayılmasında, Yemen geçiş noktası olmuştur." (Çağlayan, 2012: 97). Kahvenin 16. yüzyılda İstanbul'a gelişi ise, Misır ve Suriye üzerinden hac kervanları vasıtasıyla olduğu bilinmektedir (bkz. Hattox, 1998: 24). İçecek olarak İstanbul'a taşınan kahve, kahve satılan ve içilen mekânların açılmasıyla kendi paylaşım alanını oluşturur. 16. yüzyıldan itibaren İstanbul merkezli olmak üzere Osmanlı toplum yapısı üzerinde etkili olmaya başlayan kahvehane, dinî kurumlardan sonra ortaya çıkan sosyal paylaşım alanlarından birisidir. Özkul Çobanoğlu kahvehanenin rolünü şu şekilde açıklar:

"16. yüzyılın ikinci yarısından itibaren kahvehaneler, tekkenin karşısında bir nevi alternatif Müslüman sosyal kurumu olarak belirir ve tekkenin topluca eğlenmek ve çeşitli sosyo-kültürel faaliyetlerde bulunma tekelini kırar. Dahası tekke ekseninde uhrevi bir neşve içinde yer alan topluca 
eğlenmeler, kahvehane ekseninde nerdeyse tamamen dünyevi veya din dışı bir karakter kazanır." (Çobanoğlu, 2000: 129).

Geleneksel toplum yapısı içerisinde kamusal alan olarak "cami, hamam, bir-iki bakkal, manav ve fırından oluşan yerel çarşı ve sokak" (Özkoçak, 2010: 21) sıralanabilir. Kahvehane bu yapıya eklemlenmiş bir yeni kamusal alan statüsündedir. “Osmanlı İstanbul'unda kahvehanenin kamusal alanın başlıca mekânı olarak ortaya çıkmış ve kamusal iletişimin mevkii, kanalı ve siyasi olanla sosyo-kültürel olanı birbiriyle ilişkilendiren bir saha" olmuştur (Kömeçoğlu, 2010: 50).

Kahve içeceği etrafında şekillenen mekânlar, aynı zamanda sosyo-ekonomik ve politik değişim süreçlerinin yansıdığı önemli alanlar olmuştur. Yahya Kemal Taştan'ın ifadesiyle "Kahvenin tarihini okumak, son altı yüzyıllık dünya ekonomisini ve modernleşmeyi anlamak için önemli bir veridir." (Taştan, 2009: 82). Bu açıdan Osmanlı kahvehanelerine bakıldığında başlangıçta kahvenin tüketildiği bir mekân olarak görülürken daha sonra "kamusallığın" ve "bozucu eleştirel toplumsallığın" merkezi olarak algılanır. Çeşitli yasaklamalar getirilir. Buradaki tepki "mekânsal bir geometriye değil onun metonimik, mimik tehdidine karşı gelişir." (Kömeçoğlu, 2010: 75). Bu durum kahvehanenin toplumsal iletişim ağları içerisinde odak teşkil etmesi ve bunun yarattığı sonuçlarla ilişkilidir. "Başlangıçta kahve içilen bir mekân olan kahvehane, hayatını XVI. yüzyıl ortalarına kadar ev, cami ve çarşı arasında yönlendiren Osmanlı toplumunun gündelik hayatına geleneksel ilişkiler dışında farklı bir ilişki şeklini örgütleyen yeni bir mekâna dönüşür. Gündelik hayata katılan bütün toplumsal sınıflar arasındaki kültürel iletişim kanallarını harekete geçirir." (Tutal, 2014: 164)

16. yüzyılda İstanbul'a gelen kahve içeceği etrafında teşekkül eden kahvehane kurumu, toplumsal kültürel yapının değişmesi, siyasi-ekonomik sistemin yansımaları ve kentleşme süreçleriyle birlikte bugüne kadar varlığını korumuştur. Kahvehane, kültürel ihtiyaçlara cevap vermiş ve yeni şartlara göre kendini güncelleyebilmiştir. Osmanlıdan Cumhuriyete geçiş sürecinde kahvehanelerin kültürel ve politik açıdan bir merkez olduğu görülür. "Her türlü siyasî, sosyal ve fikirsel yeni gelişmenin tartışıldığı ve sohbetlere konu olduğu bu mekânlar bir bakıma Osmanlı'dan Cumhuriyete yaşanan Batılılaşma çabalarının ve değişimin aynası mahiyetindedir." (Ediz, 2008: 188).

Cumhuriyet sonrası dönemde Türkiye'de ekonomik ve siyasi sistemin değişmesi ve 20. yüzyıldaki hızlı sanayileşme süreci kentlerin yeni bir kültür çevresi olarak ön plana çıkmasını sağlar. Bu süreçte kahvehaneler "yeni kentlileri kente bütünleyen mekânlar" olarak görülebilir. "Kahvehaneler, kentleşme sürecinde, yeni kentlileri hem kente eklemleyen hem de kentten kopuşa/izolasyona kapı aralayan kurumlar olma vasfına sahiptirler." (Aytaç, 2005: 179). Bu süreçte kahvehanelerin toplumsal cinsiyet bakımından Osmanlıdakine benzer şekilde işlediği görülür. Erkek egemen bir toplumda geleneksel kahvehane eril bir mekândır. (bkz. Demren 2007). 
İşlevlerinin önemli bir kısmını başka kurumlara devreden kahvehane, bu özelliğini kırsal alanda ve genellikle kent çevrelerinde devam ettirir.

Kentleşme, eğitim düzeyinin yükselmesi, kadın nüfusunun gündelik hayatta evden çıkması gibi sebeplerin yarattığı kültürel talep basıncı, kahvehane modeli alınarak yeni sosyal paylaşım alanlarının ortaya çıkmasını sağlar. Özellikle kent merkezlerinde, turistik alanlarda ve üniversitelerin bulunduğu genç nüfusun yoğun olduğu bölgelerde kahvehane kurumunun, "çok amaçlı kafelere, oyun salonlarına, kıraathanelere ve kulüplere" dönüştüğü görülür (Tutal, 2014: 165). Bu süreç kapitalizm ve küreselleşmenin dayattığı mekân, tüketim ve ilişki biçimleriyle birlikte ele alınabilir. Bir taraftan küreselleşme homojen tüketim pratikleri ve mekânları ortaya çıkartırken diğer taraftan küresel olan da yereli dikkate alır. "Yerel olan küreselleşme pratikleri çerçevesinde küreseli benimserken, küresel olan yereli barındırma ihtiyacı hisseder." (Akarçay, 2012: 200). Bu bağlamda "üretim-tüketim-bölüşüm” ilişkilerinin ortasında bir içecek olan kahve ve kahvehane kurumu, doğuyla özdeşleşmiş olsa da Batı modernizminin sosyal tüketim alanlarına rol modellik yapmıştır. "Batı'da ise Doğu'dan alınan kahve ve café kültürü aydınlanma ve modernleşme süreci ile birlikte kamusal mekânlara dönüşmüştür." (Akarçay, 2012: 183). "Özellikle 20. yüzyılın son çeyreğinde Batı' dan ithal edilen ve kahvehane sınıfına dâhil olan "kafe" eki alan birçok işlev/yapı türü, bir modernlik merkezi olarak kahvehane mekânına yeni değerler eklemesine karşın kahvehanenin kamusallığını aşındırmaktan da geri kalmaz." (Tutal, 2014: 164).

Kahvehaneler işlevlerinin bir bölümünü başka kurumlara devretmişlerdir. Esra Bilge bu süreci şu şekilde özetler:

"Sanayi devriminden sonraki toplum yapısının ihtiyaçlarına özgü olarak gelişen kıraathane ve kahvehane adlı kurumlara Batılı toplumun etkisi ile oluşturulmuş olan cafe kültürü de eklenmiştir. Zaman içerisinde kahvehane ve kıraathane farklı işlevlerini bu Batılı kurumda gözlemlemek mümkündür. Doğu ile batının birleştiği bu yeni kurum kahvehane/ kıraathane/ cafe üçlüsünün birleşiminden oluşmuş olan cafe adlı kamusal mekândır." (Bilge, 2010: 105-106).

Sanayi Devrimi sonrası kalabalık kentlerin metropollere dönüşmesi, kentte ortaya çıkan yeni ihtiyaçların şekillendirdiği kafeler, kahvehanelerden farklı olarak cinsiyet ve kimlik değişimini sağlamıştır. Kahvehaneyi model alan yeni mekânlar, "sadece erkeklerin değil, aynı zamanda kadınların da eğlenme ve dinlenme mekânı olmuştur. Bu değişimde, üniversitelerde okuyan kız öğrencilerin etkisi büyüktür." (Özdemir, 2005: 130). Doğu sosyo-ekonomik sistemlerinin ürünü olan kahvehane, erkeklerin tükettiği bir mekânken Batı sosyo-ekonomik sistemlerinin ürünü olan kafe, cinsiyet ve kimlik genişlemesini getirir. Diğer taraftan kafe Batıdan esinlenen-taşınan bir kurum olmasına rağmen yerel içeriklerle birlikte yayılır. Markalaşmış Batılı kafe zincirleri, yerel içerikli kafeler karşı karşıya gelir. Kafelerde geleneksel Türk kahvesi tüketimi ve nargile yeni mekânda sunulan yerel içerikler arasında sayılabilir. Yeni 
mekân olan kafenin üretim sürecinde temel etkenlerden birisi "deneyim ekonomisi" olarak görülür. Üretici yeni mekâna ekonomik değer katmak için geleneksel içeriklerden faydalanır. Böylece müşterinin geleneksel tüketim hafızasına hitap edilmiş olur. Ayrıca bu yerler deneyimin merkezi olan mekân odaklı çalışmalarda "deneyim ekonomisinin kaçış alanı olarak tanımladığı deneyim mekânları olup Oldenburg'un üçüncü yer kavramıyla" da açıklanmaktadır. (Anlı, Yavan, 2019: 126).

Gelenek ve modernite arasında kahvehanenin işlevlerini onu model alarak üstlenen yeni kentli mekânların yerel içerikli sunumları arasında Türk kahvesi ön plana çıkar. Kahve yalnızca kahvehanede tüketilen bir ürün olmayıp halk kültürünün önemli bir parçasıdır. Kendine özgü yapım şekli olan Türk kahvesi kendi kültürünü oluşturmuştur. Kız isteme töreninde kahve içilmesi, kahveyi içtikten sonra "kahve falına" bakılması bu kültürün en iyi örnekleridir. İçecek olarak Türk kahvesinin zengin kültürel geri planının açlan modern mekânlarda kullanılması yerel markaların oluşmasını da sağlamaktadır. Mekânla birlikte içeriğin de tüketildiği bu alanlar, küresel markalarla yarış halindedir (Açıkgöz, 1999: X; Bulduk, Süren, 2008: 301; (Alıç, Alıç, 2013: 14-15). Türk kahvesi geleneksel kültürdeki yeri ve uluslararası boyuta taşınmış bir ürün olmasıyla birlikte UNESCO'nun somut olmayan kültürel miras listesine 2013 yllında girmesiyle popülerliğini arttırır. "Petrolden sonra en fazla ticareti yapılan ve dünyada sudan sonra en fazla içilen içecek olan kahve, UNESCO tarafından tescillenen ilk sıvı olma özelliğini de taşır (Koca, Tüğen, 2020: 359).

Mekânların tüketiminde, sunulan içeriklerin belirgin rol oynadığı görülür. Bu çerçevede Türk kahvesi etrafındaki "gelenek ve uygulamaların" bir kısmı kafelere de taşınmıştır. Sosyal paylaşım, sohbet ve etkileşim işlevi olan kahve, fincanın içinde kalan telvenin fal bakma aracı olmasıyla da ön plandadır. Türk kahvesine özgü fal geleneği, kentli mekân olarak kafelerin tüketiminde önemli bir cazibe unsuru oluşturur. Geleneksel toplum yapısının aksine, bu tarz tüketim, eğitim durumu yüksek, kentli ve genç nüfus arasında da yaygındır. Özellikle üniversite çevrelerinde Türk kahvesi falı bakılan kafelerin popüler olduğu görülür. (Kaplan, 2011: 18; Acar vd. 2019; 138; Balc1, 2019: 326)

Afrika'dan başlayan yolculuğa İstanbul'da mola veren kahve, pişirilme ve içilme şekliyle Türk kahvesine dönüşerek batıya taşınmıştır. Gittiği her yerde oranın kültürel yapısına uygun sosyal müesseseler kahve etrafında şekillenmiştir. Bu bağlamda Anadolu'da kahvehane, batıda kafe, tarihsel süreçte önemli sosyo-kültürel alanlar olarak ortaya çıkmıştır. Değişen ihtiyaç ve koşullarla birlikte kültür endüstrisinin bu talebe verdiği cevap, Türkiye'de kahvehanelerin işlevlerinin büyük bir bölümünü kafelere aktarımını sağlamıştır. Bir yandan küresel kafe markaları Türkiye'de yaygınlaşırken bir yandan yerli markalar oluşmuştur. Ayrıca kentli mekân olarak kafelerin geleneksel kültürel imge ve tüketim tarzlarını kullanması tüketiciler açısından önemlidir. Gelenekselin dönüştürülerek kullanılması yerli markaların rekabet gücünü arttırır. Türk kahvesinin geleneksel kültür yapısı içerisinde önemli bir sosyal bağ kurma aracı olması ve fal bakma geleneğinin bir parçası olması, kentli 
mekân olan kafelerde kullanım biçimlerini yaygınlaştırır. Kahvenin hikâyesi üzerinden kahvehaneden kafeye dönüşüm serüveni, "batının doğululaşması, doğunun batılılaşması" (Bilge, 2010: 88) şeklinde özetlenebilir.

\section{Kentli Mekânda Irkçılık/Falcılık}

Türkiye'de üretim-tüketim sistemlerinin batıdan sonra değişmesi, geç modernleşme denilen sürecin yaşanmasına neden olmuştur. 20. yüzyılın ortalarında başlayan hızlı kentleşme süreçlerinde geleneksel sosyo-kültürel kurumlar dönüşmüş veya rollerinin bölünmesiyle yeni mekânlar ortaya çıkmıştır. Toplumun geçirdiği kentleşme aşamaları bu kurumsal mekânlara yansır. Bu bağlamda kahvehane ve kafe kültürü önemli bir gösterge alanıdır. Kentli insanın mekânı tüketim tarzlarını okuyan yerli ve yabancı mekân üreticileri, geleneksel kültürel yapıdan beslenmiştir. Ortaya çıkan yeni sosyal paylaşım ve eğlence alanı olan kafe, mekânla birlikte geleneğin de tüketildiği ortamlardır. Bu çalışmada ele alınan ırk/fal bu tüketim biçimlerinden birisidir. Kentli insanın sosyal ihtiyaçlarına uygun olarak ortaya çıkan kafeler, "mekânda ihtiyaçlar ve arzular -mevcut halleriyle- yeniden belirebilir, üretmeyi ve ürünü canlandırır" (Lefebvre, 2014: 351) prensibine uygun olarak fal bakma geleneğinin kentteki merkezlerinden birisi olmuştur.

Fal karşılığı olarak eski Türkçe de "1rk" sözcüğü kullanılmıştır. Eski Uygurcada 1rk kelimesinin anlamı "işaret, rumuz, falcı" olarak verilmiştir (Caferoğlu, 1968: 87). Divanü Lûgat-it Türk'te 1rk; "falcılık, kâhinlik ve bir kimsenin gönlündekini bilmek" olarak açıklanır (Atalay, 1999: 42). Kelime 9. yüzyılın başlarından kalma "Irk Bitig" adlı Göktürk harfli eserde de geçer ve bu eser Fal Kitabı olarak çevrilir (Tekin, 2013: 13). Irk kelimesinin bugün de Anadolu'nun bazı yerlerinde geçmişteki anlam ve içeriğiyle kullanıldığı görülür (Gültekin, 2014: 119-137; Gömeç, 2019: 43).

En eski inanç sistemlerinden bu yana fal ve falcılıkla ilgili çeşitli uygulamalar toplumların hayatına yön vermiştir. Özellikle ilkel toplumlarda dini hayatın bir parçası olarak görülen fal, daha sonra ilahi dinlerle birlikte çeşitli geleneksel uygulamalarla iç içe geçerek devam etmiştir. Bugüne göre, ilkel insan ve toplumun benliğini yönlendiren metafizik unsurlar daha fazla görülür. Bu durum bütün kültürel hayata yön verecek kadar belirginleşebilir. "İlkel ve geleneksel toplumlarda büyü, fal ve ona ilişkin benzer inanışlar iktidar, ekonomi gibi toplumsal kurumları etkileyen, dahası sosyal-kültürel yapıyı şekillendiren ayırıcı bir güç olmuştur. Günümüz toplum anlayışında ise bu tür inanış biçimleri her ne kadar marjinal olarak kabul edilse de, sosyo-kültürel yaşamda etkinliğini giderek arttıran bir olgu haline gelmiştir." (Nar, 2014: 508).

Bu çerçevede eski Türklerde fal ve falcılıkla ilgili uygulamalara bakıldığında toplumsal aksiyonu, toplumun bilicisi denilen dinî hüviyetteki kişilerin fal ve benzeri uygulamalarla yönlendirdiği söylenebilir. Bu çerçevede Abdulkadir İnan'a göre "falcılık şamanizmin başlıca unsurlarından birisidir." İnan, falcıların fal açmak için 
kullandıkları nesneye göre farklı adlar aldığını söyler. Eski Türklerde "hayvanların kürek kemiğine bakıp geleceği keşfedenlere "yağrmcı" koyun tezekleriyle fal açanlar "kumalakçı" muhtelif şeylerden manalar çıkaran falcılara "ırımçı" denir." (İnan, 1989: 151-152). Fuzuli Bayat şamanların devlet meselelerinden şahsi meselelere kadar her konuda başvurulan kişiler olduğunu ve onlara fal açtırmanın çok eskilerden beri yaşayan bir gelenek olduğunu söyler (Bayat, 2004: 109).

Eski inanç sistemleri içerisinde din adamlarının birden fazla rolü vardır. "Büyü yapmak, yağmur yağdırmak, bitki ve hayvanların çoğalımını sağlamak, fala bakmak vb. gibi büyüsel işler de uğraşı alanlarının içine girer." (Örnek, 1998: 54). Örneğin "Türk şamanlarının işlevlerinden birisi de "fal bakarak gelecekten haber vermedir"(Bayat, 2006: 23). Şaman, aynı zamanda sanatçı, öğretici, doktor ve öngörücüdür. Fuzuli Bayat eski Türk dini içerisindeki şamanlarla ilgili şu tespiti yapar:

"Şaman hastalığı tipindeki hastalık, vergi alan bütün insanlarda; demircide, tabipte, hebacılarda, ozanlarda, bahşılarda, âşıklarda, falcılarda vb. görülmektedir. Ruhların dilinden şiir veya dua söyleyen, kozmik bilgileri sembolik bir dille topluma ileten, tedavi eden, gelecekten haber veren bu insanların durumunu hastalık adı altında değerlendirmek değil, etno-psikolojik kültür hadisesi olarak değerlendirmek doğru olur. (Bayat, 2006: 42)

Eski Türklerde kadın şamanların da sosyo-kültürel yapı içerisinde belirgin rolü vardır. Falcılık bunlardan birisidir. "Sözlü gelenekler, arkeolojik kazılar ve tarihi veriler kadınları şifacı, otacı, kahin, falcı, kendinden geçen dansçı, kozmik yolcu olarak gösterir. Kadınlar en eski sağaltma metotlarını iyi bilen ve bunu başarıyla tatbik eden kişilerdir (Bayat, 2010: 22).

Pertev Naili Boratav geçmişten bu yana Türklerde falcıların "tekniklerine, uzmanlıklarının niteliklerine, kullanılan gereçlere ya da yorumlanması beklenen olaylara göre çeşitli biçimlerde kümelenebileceğini" söyler. Boratav Türklerde öne çıkan fal türlerini "suya bakma, aynaya bakma, kurşun-köz-tütsü, kürek kemiği, kahve falı, iskambil falı, bakla falı" şeklinde sıralar (Boratav, 1994: 101-103).

Fal geleneği Türklerin İslam’ı kabulünden sonra da devam etmiştir. Osmanlı döneminde falcılar "esnaf" kimliği taşımış ve "müneccimler, remilciler, resimli falcılar" şeklinde sınıflanmıştır. Özel bir uzmanlık gerektirmeyen kitap falları, "bir kitabın rastgele bir sayfasının, niyet tutularak açılması temeline dayanır ve bu fal, belirli satırdaki harf ya da sözcügün yorumuyla bakılır. Bu fal için çeşitli yöntemler ve kitaplar yazılmıştır. Falnâme adıyla anılan bu kitapların, fal için kullandırdıkları kitap çoğunlukla Kur'an'dır." (Sezer, 1998: 10).

Geçmişten bugüne fal geleneği toplumsal hayatın içerisinde önemli yer bulmuştur. Değişen yaşam şartları, insanın doğa ve metafizik algısı, eğitim düzeyi gibi etkenler, geçmişi anlama ve geleceği bilme merakını gidermemiştir. Gündelik hayat içerisinde "olağanüstü iletişim değerine inanış, memoratlaşarak" (Çobanoğlu, 2003: 
219) insan ve toplum hayatında varlığını sürdürmüştür. Pek çok bilim dalının dikkatini çeken fal, antropolojik anlamda "kültürel bir olgu ya da kültürün bir yansıması olarak ortaya çıkabilen davranış biçimi olarak açıklanabilir. Bu yönüyle fal inancı, kültürün, psikolojik ihtiyaçları giderme temelli-kültürün soyut yönünü temsil eden- bir dizi yaklaşımla karakterize edilebilir." (Nar, 2014: 511).

Gündelik hayat içerisinde en yaygın fal bakma biçimlerinden birisi, kahve falı olarak görülür. 16. yüzyılda İstanbul'a gelen ve kendi mekânını yaratıp kahvehaneden kafe türlerine dönüştürecek kadar güçlü bir içecek olan kahve, eski kültürün uzantısı olan fal bakmanın da aracına dönüşmüştür. Çeşitli geleneklerin göstergesi haline gelen kahve, sosyal paylaşım ortamlarının simgesi olmuş ve insan ilişkilerinde atasözlerine dönüşecek derecede etki etmiştir. Sosyal hayatta "Bir fincan kahvenin kırk yıl hatırı vardır." sözüyle önemli bir ölçüt olmuştur. "Kahve falı, görünürdeki, gelecekten haber verme işlevinin yanında, içerik açısından incelendiğinde katılımcların ideolojilerini yansıttıkları bir araç olma özelliğine de sahiptir." (Yokarı, 2014: 53).

Fal bakmanın dini-mistik işlevle başlayan süreci bugün mesleğe dönüşmüştür. Hem fal bakanlar hem de baktıranlar açısından önemli bir kültürel paylaşım biçimidir. $\mathrm{Bu}$ süreçte kullanılan dil üzerinden toplumların kültürel iletişim biçimlerinin anlaşılması açısından önemli verilere ulaşılabilir. Bu kapsamda Dell Hymes'in "Foundation in Sociolingouistics" (1974) adlı çalışmasında ele aldığı "konuşmanın etnografyası" kavramı, dilin yalnızca bir lengüistik malzeme olmadığını, aynı zamanda analiz edildiğinde iletişim ve kültürel içerik boyutu olduğunu gösterir. Kişilerin ve toplumların kültürel yapıları ve geçmişleri, dilin veri alanı olarak kullanılmasıyla anlaşılabilir (Hymes, 1974: 4-5).

Kent ortaminda mekânla birlikte geleneğin de tüketildiği bir alan olarak fal kültürünün gündelik hayattaki boyutu konusunda kafelerde fal bakan kişilerden anket ve mülakat yöntemiyle bilgi alınmıştır. Yeni kültürel tüketim tarzlarının falcısı olan bu kişilerin görüşleri, fal kültürünün ve bugünün toplumunun bu kültüre yaklaşımı konusunda önemli veriler sunmaktadır. Yapılan görüşmelerde kaynak kişilere fal denilince aklınıza ne geliyor sorusu sorulduğunda bir kısmı cevap vermezken bir kısmı hissiyat (KK1), yalan (KK3), enerji (KK4), para (KK5), insanlara yardım etmek (KK6) şeklinde cevaplar vermiştir.

Geleneksel kültürel aktarım biçimlerinin değişmesi ve elektronik kültür ortamının baskısı, fal bakmayı öğrenme yöntemlerini değiştirmiştir. Kaynak kişilere fal bakmayı kimden ve nasıl öğrendiniz sorusu yöneltilmiş ve farklı cevaplar alınmıştır. Fal bakanların bir kısmı fal bakmayı kendi kendilerine ve bulundukları kafe ortamında öğrendikleri belirtmişlerdir (KK2, KK3, KK8, KK9, KK10). KK2, 12 yaşında gördüğ̈ bir rüyada fincanla fal baktığını ve bu olaydan sonra fal bakmaya başladığını söylemiştir. KK4, Batı Dilleri ve Edebiyatı mezunu olduğunu ve bölümdeki Hintli bir hocasının enerji konusunda telkinleriyle bu alana yöneldiğini söylemiştir. Aynı kişi, evrende her şeyin enerjisiyle var olduğunu ve insan kendi enerjisini doğru kullanmaya başlayınca pek çok şeyi anlayabilecek gücü olduğunu ifade etmiştir. Faruk Gören adlı 
KK5, fal bakmayı "el almak" yöntemiyle geleneksel aktarım biçimi şeklinde öğrenmiştir. Bir çeşit kut taşıyıcılığı olan "kut ve kutsalla" ilişkinin kan esasına dayalı aktarım biçimlerinden biri "el vermek, el almak" şeklindedir (Öncül, 2010: 1285). Bu durumu kendisi şu şekilde anlatır: "Benim babaannem fal bakardı. Bütün köy ona fal baktırırdı. Ama sadece fala bakmazdr; büyü bozar ve cin kovalardı. Yalnız kalmasın diye onun yanında kalırdım, orada büyüdüm. Yanında yardımcıya ihtiyacı olurdu. Ben yardım ederdim. Bu süreçte merak etmeye başladım ve çocuklara bakıyordum köy yerinde. Babaannem bunu duyunca beni dövdü. Ama sonra kendisi öğretmeye başladı. 18 yaşlarında bana el verdi. Zaten her şeyi öğretmişti. O vefat ettikten sonra ailemin yanına döndüm. O zamanlarda da komşulara bakıyordum. Ev dolup taşmaya başladı. Babam bir gün eve geldi kadınları başıma toplayıp fal baktı̆̆ımı gördü. Önce kadınları kovdu, sonra beni bir güzel dövdü. Erkek kısmı kadınlarla falcılık mı oynar, adam gibi bir iş yap dedi. O günden sonra üniversiteye kadar kimseye fal bakmadım." İran'ın Tahran şehrinden gelen KK6, fal bakmayı öğrenmesini şu şekilde anlatmıştır: "Benim annem kuafördü Tahran'da. Orda pek çok Ermeni ve Rus müşterisi vardı. Onlar fala bakardı. Ben de onlardan görerek ilgimi çekti ve öğrendim. 18-19 yaşlarmdayken arkadaşlar arasında bakmaya başladım. Daha sonra, iskambil kâğıt, tarot, kahve, yıldız-name gibi farklı fal türleri öğrenmeye başladım." KK7 ve KK11 numaralı kaynak kişiler bulundukları sosyal ortamları gözlemleyerek ve kafelerde fal bakan arkadaşlarından öğrendiklerini belirtmişlerdir.

Kaynak kişiler, genellikle fal bakmaya başlamalarına neden olan olağanüstü bir olay olmadığını belirtmişlerdir. Çoğunlukla alışkanlık ve iletişim becerisi şeklinde cevaplar verilmiştir. KK4, aldığı biyo-enerji eğitiminden sonra fal bakmaya başladığını söylemiştir. KK7 fal bakmaya başlamasını şu şekilde açıklamıştır: "O dönemde astronomiye olan merakım sayesinde zamanın doğrusal bir şey olmadığı yalnızca bizim âcizane algılarımız tarafından doğrusalmış gibi algılandı̆̆ımı ve geleceğin hatırlanabilir olduğuna dönük çalışmalar okudum. Sezgilerimin güçlü olmasını ve birtakım rüyalarımın geleceği göstermesini buna yorarak fal bakmayı bu konuda bir araç olarak düşünmeye ve değerlendirmeye başladım." 8 numaralı kaynak kişi fal bakmaya başlamasının sebebini şu şekilde açıklamıştır: "Günlüğ̈̈̈me gelecekte bir tarihe bir not düşüp, o gün çok üzüleceğim bir şey olduğunu yazmıştım. Tamamen hislerim yaptırmıştı bunu bana. Sonra o tarihi tamamen unuttum. Ve uzun süre sonra defterimi elime aldı̆̆ımda geçmişte aldı̆̆ım o not gözüme çarptı. Tarih de not da eskiydi. Tarihi görür görmez hatırladım ki çok sevdiğim bir yakınımı kaybetmiştim o tarihte. O süreçten sonra sezgilerimi somut olarak da kendime kanıtladı̆̆ım için fal bakmaya başladım."

Kaynak kişiler baktıkları fal türlerini his, kahve, tarot, fal kitabı (Ahmediye Kitabı, KK4, KK10), su, kâğ1t, el, nohut, iskambil, yıldıznâme, remil, ateş, ebcednâme, kemik ve deri şeklinde belirtmişlerdir. Geleneksel falların dışında yeni fal türleri konusunda görüşleri de sorulmuştur. Bu konudaki görüşünü KK7 şu şekilde ifade etmiştir: "Her ne kadar birçok günümüz astroloğu yıldız haritasının fal ile hiçbir bağlantısının olmadığını düşünseler de ben de başka bazı astrologlar ve birçok fal müşterisi gibi esasında yıldızlarm hem geçmiş hem de gelecekle ilgili bazı sinyaller verdiğini düşünüyorum. Bu düşünceden hareketle yıldız haritası yorumlama işinin falın bir biçimi olduğunu 
söyleyebilirim." KK8 fal için kullanılan araçlara dikkat çekmiştir. "Her zaman yeni fal biçimlerinin gelişebileceğine inananlardanım. Çünkü falda esas mesele histir, nereye bakarsanız bakın görürsünüz, fincan ya da kâğıtlar bahanedir. Benim bildiğim yeni fal biçimleri yok hepsi eskilerden farklı araçlara uyarlamadır." Benzer şekilde KK11 de önemli olanın enerjinin alındığı araç olduğunu belirtmiştir. "Zaten kahve falı ve tarot yeterince geniş. Bu iki fal bile başlı başına insana çok fazla yol gösterir. Diğer fal çeşitleri tamamen falcmın nelerden enerji

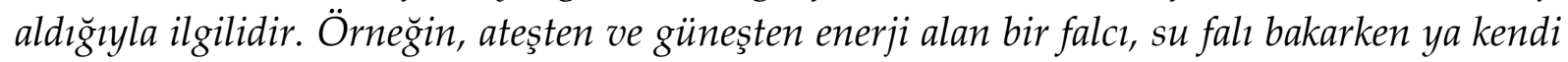
rahatsız olur ya da fal baktıran kişiyi rahatsız eder. Bu tamamen enerji meselesi."

Kaynak kişiler kafelerle birlikte telefonla, online ortamlarda ve evlerinde fal baktıklarını belirtmişlerdir. Çoğunluğu kafe sahiplerinin izni olmadan mekân isimlerinin kullanılmasını istememiştir. Oxygen Kafe (KK1) ve Ferhangi Kafe (KK4) fal bakılan yerler arasındadır. Beş kaynak kişi fal bakmayı bir meslek olarak görmediğini belirtmiştir (KK1, KK2, KK4, KK6, KK11). Kaynak kişilerin bir kısm1 ise fal bakmanın ekonomik getirisi olduğu için meslek sayılacağını söylemiştir (KK3, KK5, KK7, KK8, KK9, KK10). Fal bakmanın ekonomik değeri konusunda kaynak kişilerle yapılan görüşmelerde tamamı aynı cevabı vermiştir. Bir kısmı üniversite öğrencisi olan kaynak kişilerin fal bakmaya başlaması veya başladıktan sonra sürdürmesinin sebebi ekonomik getirisi olmuştur. KK6 kendi sürecini şu şekilde aktarmıştır: "Fal baktı̆̆ım insanlar para teklif etmeye ve para kazan demeye başladılar. Iran'da çok müşterim vardı. Hatta bir tanesi bizim eski Şahımızın eşiydi. Beni evine davet etti ve birkaç gün misafiri oldum. Para istemedim ama para vermişti. Sonra Türkiye'ye geldim. Burada da fal bakmaya başladım. Yine komşulara, arkadaşlara bakıyordum. Bir komşum bir gün fal baktıktan sonra "Müjgan sen çok iyi fal bakıyorsun. Niye evde boş duruyorsun ki fal bak, para kazan." dedi. O an için "Tamam, olur." dedim. Sonra evime geldiler müşteriler, ben onlara gitmeye başladım. Sonra Ekin Pastanesinde işe başladım. Orda mutfak içinde çalışıyordum, orda da ustalar anladı fal baktığımı, bana fal baktırmaya başka ustalar da geliyordu. Ama onlardan para almıyordum. Zaman geçti böyle, benim ustam vardı Fatih Usta bir gün "Müjgan sen neden böyle işler yapıyorsun ki, fal bakmaya başlasana" dedi. Ardından Çamlıca Kafede başladım, İbrahimlide başka bir kafede de çalıştım. Böylece profesyonel olarak fal bakmaya başladım."

Kaynak kişiler fal baktırmaya gelen kişilerin yaş aralığı konusunda tutarlı cevaplar vermiştir. Fal baktırmaya gelenler yaş aralığı genel olarak 18-50 şeklinde belirtilmiştir. Fal baktırmaya gelenlerin çoğunluğunun kadın olduğu söylenmiştir. Fal bakan kişilerin, fal baktıranların bu konudaki beklenti ve tutumları konusundaki görüşleri gözlemlerine dayanmaktadır. Fal baktıran kişiler, genellikle gündelik hayatın meseleleri hakkında konuşmak ve olumlu telkin almak için bu yola başvurmaktadır. "Fal baktıranların, duymak istedikleri söylendiğinde mutlu olmakta ve olumlu dönüş yapmaktadırlar. Bu durum hayata karşı bir motivasyon aracıdır. (KK8). Ekonomik problemler, özel hayat, eğitim hayatı, sağlık gibi konuların ön plana çıktı̆̆1 görülür. Özellikle gençlerin fal baktırma merakını KK7 şu şekilde değerlendirmektedir: "İnsanlar varoluşlarından bu yana 'şimdi' ki anın sınırlarını zorlayıp geleceğin bilgisine erişmek için bir takım araçlara başvurmuştur. Bu durumun onların bilinmezlikle alakalı korkularından kaynaklandiğını düşünüyorum. En çok bilemediğimiz 
şeylerden biri de gelecektir. Bu nedenle geleceği merak etmek ve bilinmezliğin şüpheli gizemini bir nebze olsun gidermek adına bu tür yollara başvurmaktadır. Insan hayatın ise kendi içinde dönemlere bölecek olursak özellikle de günümüz şartlarında geleceğe ilişkin planların ve öngörülerin en belirsiz olduğu dönem gençlik dönemi olduğu için onların fala arzularını bu dönemlerine yoruyorum." Fal baktırmak gündelik hayat içerisinde bir çeşit terapi işlevi görmektedir (KK9). Fal baktıranlar, fala samimi olarak bakılması ve kısa sürmemesi en önemli beklenti olup o enerji ve olabilirliği hissetmek isterler (KK1, KK2). KK5 fal baktıran kişilerin geleceği bilme ve rahatlama çabasına dikkat çekmiştir: "Geleceği bilmek istiyorlar. Ama bu bilme isteği o kadar yoğun ki her şeyi bilmek istiyorlar. Diğer taraftan her insan onu rahatlatacak pozitif şeyler söyleyecek birisini arıyor. Araştırın bakın bu durum psikolojik bir şeydir zannımca. Insanda o ego denen şeyin okşanması gerekir; fal baktıranlar ise bunu parayla yaptırır. Terapi gibidir, ama yönünü senin belirlediğin bir terapi. Falcıların olumsuz bir haber verdiği çok nadirdir. Kim parasıyla kötü bir haber almak ister ki". Kaynak kişiler, insanların fal baktırmasının doğrudan inanışla ilgili değil; ancak inanma ve telkin noktasında meyilli olmayla ilişkisini vurgulamışlardır. Bu konuda KK11 şu değerlendirmeyi yapmıştır: "Ben genellikle kötü ya da gerçekçi konulara girdiğim için inanmak istemiyorlar ama içinde de bir şüphe kalıyor aslında. Genel olarak fala inanmadığı halde baktıran görmedim. Hatta bazen çok fazla inandıkların söyleyebilirim. Bir falcının söylemiyle evliliğini bitirme kararı alan insanlar tanıdım."

Kafelerde ve kentin diğger ortamlarında fal baktıranların toplumun çeşitli kesimlerinden insan olduğu saptanmıştır. Kaynak kişiler her meslek ve sosyal kesimden insanın fal baktırmaya geldiğini belirtmişlerdir. Öğrenci, öğretmen, hukukçu, mimar, esnaf, polis, ev kadını bu konuda verilen cevaplar arasındadır. Kafelerin bulunduğu bölgenin sosyo-ekonomik yapısına göre fal baktıranların profili değişebiliyor (KK7). KK4 bu konuda şu bilgiyi vermiştir: "Köy yerinde öğrendim ben bu işleri okumamış kesimde baktırıyordu ve ODTÜ gibi bir yerde para kazanmaya başladım. Okumuş hatta ülkenin en prestijli yerinde okumuşu da fal baktırıyor. Şimdilerde ise fala inanan herkes baktırıyor. Zengin fakir fark etmiyor. Burada kimlere baktığımı isim isim vermek uygun olmaz."

Kafelerde fal baktıranlar ve fal bakanlar arasındaki sosyal ilişki daha sonra da devam etmektedir. Kaynak kişilerle yapılan görüşmelerde fal baktıranların daha sonra geri dönüş yaptıkları söylenmiştir. Olumlu veya olumsuz tepki şeklinde olan bu dönüşler, müşteri memnuniyeti olarak görülebilir. Kaynak kişilerin tamamı geri dönüşlerin olduğunu belirtmiştir. KK7'nin bu konudaki ifadesi şu şekildedir: "Benim müşteri kitlem genellikle aynı kişilerden oluşuyor. Haftada bir, bazen haftanın birkaç günü düzenli biçimde yapılan bu fal ziyaretleri sırasında bir önceki fala dair de konuşmalar yapılıyor. A ğırlıklı yorumlar olumlu yöndedir."

Kaynak kişilerin kafelerde fal kültürü konusundaki görüşleri sorulmuş ve genel olarak falın modern çağa uygun biçimde kullanıldığı ifade edilmiştir. KK10, uhrevi ortamın tam olarak yakalanamamasına rağmen kafelerin fal baktırma işlevinin devam ettiğini söylemiştir. Ona göre; kafede fal konusu, "hobi tarzı bir durum veya kahve 
satışında ekonomik bir rekabet" unsurudur. KK11 bu konuda şu yorumu yapmıştır: "Aslında egzotik ve sürpriz bir durum olarak görüyorum. Kimsenin aklında fal baktırma olayı olmadığında bile bir anda karar verip baktırmaları çoğu kişiyi mutlu edebiliyor. Bu yüzden pratik diyebilirim."

Fal kültürünün geleceği konusunda kaynak kişilere sorulan sorulara verilen cevaplarda çoğunlukla, bu kültürün devam edeceği görüşü çıkmıştır. Bunun sebebi insanın merak duygusunun sonsuzluğu ve falın işlevleri olarak yorumlanmıştır. Hem kültür hem de meslek olarak fal bakmanın gelecekte devam edeceği görüşü aktarılmıştır. Kentleşmeyle kafelere taşınan fal kültürünün teknoloji karşısındaki dururumu fal bakan kişiler tarafından yorumlanmıştır. Özellikle elektronik ortamdaki fal uygulamalarının ve online fal bakma ortamlarının, yüz yüze fal bakma kültürüne etkisini değerlendirmeleri istenmiştir. Kaynak kişilerin çoğunluğu elektronik kültür ortamındaki fal uygulamalarının ve diğer içeriklerin kalıcı olmayacağı kanaatindedir. Bu uygulamaların insanların dünyasında yeterli tatmini sağlamayacağ1 söylenmiştir. KK7 bu konuda şu yorumu yapmıştır: "Son dönemlerde ortaya çıkan fal uygulamalarının insanları bir makinanın geleceklerini söylemesi konusunda şaşırttığını düşünüyorum. Fakat bunun bir devamlılık să̆layacağını düşünmüyorum." Benzer şekilde KK9 şunları söylemiştir: "Hiç bir android fal, kitlesini, canlı bir insanın tatmin ettiŏi kadar etmeyecektir. Bunun sebebi ise insanların her zaman bir adım daha somut varlıklar olması. Böyle oldukları sürece insanlar düşünebilir ve yorum yapabilir bir canlidan yorum istemeye devam edeceklerdir." KK8 konunun başka bir yanına dikkat çekerek kahve içilen fincanı isteyen müşterilerin, resimleri fal uygulamalarına gönderdiğini ifade etmiştir.

Geleneğin kent ortamında yeni bir tüketim biçimi olarak kafelerde fal bakma kültürü mekânla birlikte içeriğin de tüketimine örnek teşkil eder. Kentli insanın gündelik hayat kaygıları içerisinde başvurduğu bir sağaltım alanı olan fal kültürünün, kentteki sözlü kültür ortamında yaygınlaştığ görülür. Fal baktıran kişilerin gittikleri kafeler ve falcılar hakkındaki olumlu söylemleri mekânın ve fal bakan kişinin kent ortamında popülerleşmesini sağlar.

Yazılı ve elektronik kültür ortamında yansımaları olan fal ve benzeri uygulamalara dayalı kültürel pratiklerin geri planında kültür endüstrisinin olduğu söylenilebilir. Adorno, "Basındaki fal sütunları halklara verilen resmi talimatlara denk düşer." (Adorno, 2005: 249) yorumunu yaparak bu durumu eleştirir. Sözlü kültür ortamında tüketimin odağındaki fal kültüründe insan ve iletişim unsurunun ön plandadır. Şehir çalışmalarında "sosyal ve kültürel mekân” (Yaşar, 2005: 237) olarak ele alınan kentli mekân, söz konusu iletişim biçiminin yapay ortamıdır. Bu kapsamda kentli mekân olan kafe, mekânsal özelliklerini batıdan almış olsa da yerel sosyokültürel özelliklere sahiptir. En eski geleneksel yöntemleri içerisinde barındıran fal kültürü, yeni mekânda kentli insanın beklentilerine cevap vermektedir. Hızlı kentleşme, sosyo-ekonomik problemler, elektronik kültür ortamının ortaya çıkarttığı bilgi yığını gibi etkenler kent insanının kendini rehabilite edecek alanlar aramasına yol açmıştır. 
$\mathrm{Bu}$ durum karşısında arayış içerisindeki insanın kolay erişebilecek ortamlarından birisi, belirsiz ve mistik mikro alanlar sunan fal bakılan kafeler olmuştur. Kafelerde Türk kahvesinin tüketimi ve kahve fincanıla bakılan fal türü, diğer fal çeşitlerinden daha fazla rağbet görmektedir. Bu da mekânın ve içeceğin tüketilmesiyle ilgilidir. "Bireylerin ucuz ve kolay yoldan psikolojik destek alarak rahatlamaları da kahve falının işlevselliğini devam ettireceğine dair güçlü bir işarettir. Günümüzde yaşam koşulları ve yoğun iş temposuna eklenen aile içindeki bazı problemler, ekonomik zorluklar, sağlık sorunları, duygusal ilişkilerde yaşanan sıkıntılar, üzüntüler, eğitim-öğretimle bağlantılı bazı kaygılar devam ettikçe, kahve falına bakan kişilere duyulan ihtiyaç devam edecektir." Kafeler bu ihtiyacı görerek "Kahvesi sizden falı bizden" sloganıla süreci yönlendirmektedir." (Büyükokuta, 2012: 108; İslamoğlu, Binark, 2012: 534).

Diğer taraftan kafelerde fal bakan kişilerin sözlü kültürün temel unsuru olan iletişim konusundaki becerileri ön plana çıkar. "İlkel dinlerden bu yana kâhinler, falcılar ve yorumcular" (Malinowski, 1990: 46) toplumsal hayatın içerisinde metafizikle insan arasındaki bağı kuran kişiler olmuşlardır. Kent ortamında fal bakan kişiler bugünün dünyasında benzer bir bağı sağlarlar. Fal performansı, çeşitli dilsel "yöntemleri" ve ikna biçimlerini içerir. Falın "belleğe yerleşmiş olan kadınsılığı, fala bakan kişilerde de kendisini göstermekte, erkek falcılar, kendilerinin eşcinsel olduklarını iddia etmektedirler ve bu şekilde her iki cinsin dikkatini çekmekle birlikte güvenini sağlayabilmektedirler." (Yokarı, 2014: 16).

Fal kültürünün kentli insanın dünyasındaki yeri, ilkel insanınkinden anlamsal olarak farklı değildir. Abdulkadir İnan bu konuda şu tespiti yapar: "Fal baktırmak, iptidai şamanizmin bütün kişioğlunun ruhunda bıraktığı ve tedavisi kabil olmayan hastalıklardan biridir. Bir Altaylı kamın kürek kemiği falıyla, olgun topluluktaki aydın salon hanımlarının ve madamlarının iskambil veya kahve telvesi falı arasındaki fark ancak maddedeki farklardır. Mana bakımından bu fallar arsında en ufak fark bile yoktur." (İnan, 1989: 159). Ayrıca bugün, kentleşme ve iletişim teknolojileri fal kültürünün kent ortamında yaygınlaşmasına ve "popüler kültürün parçası" (Halıcı, 2018: 146-159) haline gelmesine neden olmaktadir.

\section{Sonuç ve Öneriler}

Bu çalışmada ele alınan kentli mekânla birlikte geleneğin tüketim biçimi olarak fal kültürü, en eski inanç sistemlerinden bugüne varlığını korumuştur. Toplumların yaşam biçimlerinin değişmesiyle, birtakım gelenekler yeni kültürel ortamlara uyum sağlar. Avrupa' da ortaya çıkan Sanayi Devrimi sonrası, toprağa bağlı yaşam biçiminin yerini sanayi toplumu alır. Bu bağlamda Türkiye' de 20. yüzyılda önemli değişmelerle birlikte kentleşme süreci hızlanır. Kent ve kent çevresinde nüfusun yoğunlaşmasıyla yeni yapılanmalar oluşur. Bu süreçte kentli insanın kültürel hayatı yeni fizikî ve sosyal çevreye göre şekillenir. Yeni üretim-tüketim biçiminin yansıması olarak kent ortamındaki mekânlar, sosyal paylaşım ve aktarım alanları olur. Bu süreci şekillenmesinde iç dinamiklerin talep ve ihtiyaçları olduğu kadar, kapitalizm ve 
küreselleşmenin dayatmaları da etkilidir. Kültür endüstrisinin ortaya çıkardığı basınç, kent hayatındaki fizikî ve sosyal kültürel yapıların şekillenmesine yön verir.

Geleneksel mekân olarak kahvehane ve kentli mekân şeklinde tanımlanan kafe, söz konusu bu sürecin ortaya çıkardığı mekânsal dönüşümü yansıtır. Kahve bitkisinin içeceğe dönüşmesi ve Afrika'dan Avrupa'ya uzanan taşınma sürecinde İstanbul önemli bir duraktır. 16. yüzyılda İstanbul merkez olarak kahvenin satıldığı ve içildiği mekânlar kahvehanelerin ortaya çıkmasını sağlamıştır. Kahvehaneler, Osmanlı ve Cumhuriyet dönemlerinde bir çeşit seküler alanlar olarak sosyo-kültürel hayatın merkezinde olmuştur. Geleneksel toplum yapısında gündelik hayatın bir çatı kurumu olarak kahvehanenin birden fazla işlevi vardır. Kahvehane bu işlevlerinin bir kısmını, değişen hayat şartları ile birlikte başka mekânlara aktarmıştır. Kent ortamında bilinen özelliklerini kahvehaneler kenar mahallelerde korurken, kafeler de yeni mekânlar olarak gündelik hayata girer. Toplumsal cinsiyet açısından eril bir mekân olan kahvehane karşısında kafe, cinsiyet sınırlamasının kalktığı yerdir. Bu değişim, kentleşme, eğitim seviyesi, kadının iş gücüne dâhil olması gibi sebeplerle doğan yeni sosyal ihtiyaçların sonucudur.

Mekânın tüketimi bağlamında kafeler, ekonomik değer bakımından mekân ve içecekle birlikte kültürel yapıları da kullanır. Yerel kültürel tarzlar mekânların şekillenmesinde etkili olurken geleneksel kültür unsurları da yeni mekânın sunumları arasına girer. Bu yerelleşme, tüketicinin kültürel belleğini kullanarak ürün satma amacı taşır. Çalışmada konu edilen fal kültürü bu unsurlardan birisidir. Eski Türk inanç sistemi içerisinde önemli bir yeri olan fal kültürü, Türklerin İslâm inanç dairesine girmesiyle birlikte zenginleşerek devam etmiştir. Türkçenin erken dönem sözlü ve yazılı metinlerinde "1rk" olarak geçen fal kelimesi, bugün de Anadolu'nun çeşitli yörelerinde eski anlamlarıyla kullanılmaktadır. Yaşanılan fiziki ve kültürel ortamların da etkisiyle pek çok fal türü kullanılmıştır. İnsanın geleceği bilme merakı, falcı olarak bilinen aracılar vasıtasıyla farklı ortamlarda devam etmiştir. Kentte gündelik hayatta bu ortamlardan birisi fal bakılan kafeler olmuştur.

Çalışmada mekânın dönüşümü ve yeni mekânda geleneğin tüketim örneği olarak ele alınan fal kültürü incelenmiştir. Bu kapsamda kafelerde aktif olarak fal bakan 11 kaynak kişiyle görüşülmüştür. Bu kişilerinin bir kısmı birden fazla kafede fal bakmaktadır. Bu kişiler arasında KK5 babaannesinden bir geleneksel bilgi aktarım sistemi olan "el almak" kaydıyla fal bakmaya başlamıştır. Diğer kaynak kişiler, kişisel hayat deneyimleri veya bulundukları ortamların katkısıyla fal bakmayı öğrenmiştir. Çalışmada kaynak kişilere yöneltilen sorular, fal bakanların gözünden kent insanının kültürel tüketim tarzlarını anlamaya yöneliktir. Özel hayat, sağlık, eğitim, ekonomik durum gibi konular fal baktıran kişilerin merak ettikleri konular arasındadır. Fal bakan kişiler, fal bakmanın ekonomik getirisinin olduğunu bu işi bu yüzden yaptığını belirtmişlerdir. Bu veri, yeni sosyo-kültürel yapıda geleneğin kültür ekonomisine dönüşmesine örnek teşkil eder. Fal baktıran müşteriler toplumun her sosyo-ekonomik kesiminden ve yaş grubundan olabilmektedir. Çoğunlukla kadınlar fal 
baktırmaktadır. Bazen batıl inanç ya da hurafe şeklinde açıklanan fal kültürü, hem fal bakanlar hem de fal baktıranlar açısından belirli bir eğitim düzeyindeki insanlar tarafından benimsenmiştir. Bu da okur-yazar kent insanının falı, hayat karşısında bir çeşit terapi olarak gördüğü ve fal bakılan kafeleri mistik sığınma alanlarından birisi şeklinde yorumlanabilir. Kafede fal bakan kişiler, performanslarıyla kendi kişisel deneyimlerini iletişim becerisine dönüştürerek insanlara sunmaktadırlar. Bu durum konuşmanın etnografyası açısından önemli bir kültürel paylaşım biçimidir.

Fal kültürünün kent ortamında ekonomik, kültürel ve psiko-sosyal boyutları vardır. Fal bakılan kafeler ve bu kafelerdeki falcılar, mekânla kültürel belleğin kesiştiği noktada bulunur. Kahve içeceği etrafında teşekkül eden kahvehane kültürü, ulaşımiletişim çağında kafeye dönüşmüştür. İlkel insanın hayatın bilinmezlikleri karşısındaki arayışlarından birisi olan fal, yeni araçlar ve mekânlarla bugünün insanının gündelik hayatında da varlığını sürdürmektedir. Kentli insan, kapitalizm ve kültür endüstrisinin de dayattığı yeni mekânı tüketirken, geleneksel olanı da tüketir. $\mathrm{Bu}$ çerçevede toplumun bilgi ve dünyayı algılama düzeyi değişse de kent ortamında fal kültürünün gelecekte var olacağı söylenebilir.

\section{Kaynakça}

Acar Neşe, Çakırbaş Ali, Çizmeci Bülent. (2019). Türk Kahvesi Tüketilen Mekânların Seçimini Etkileyen Faktörlerin Belirlenmesi: Nevşehir Örneği. Anemon Muş Alparslan Üniversitesi Sosyal Bilimler Dergisi, 7(1) ss. 135-143.

Açıkgöz, Namık. (1999). Kahvenâme. Akçağ Yayınları, Ankara.

Adorno, W. Teodor. (2005). Minima Moraila. Metis Yayınları, İstanbul.

Adorno, Theodor W. (2011) Kültür Endüstrisi Kültür-Yönetimi. (Çev: Nihat Ülner, Mustafa Tüzel, Elçin Gen), İletişim Yayınları, İstanbul.

Akarçay, Erhan. (2012) Kâh Kahvehane Kâh Café: Küreselleşen Eskişehir'de Kahve Tüketimi Üzerine Kuramsal Bir Giriş. Galatasaray Üniversitesi İletişim Dergisi, Say1, 2, ss. $181-202$.

Alıç, Serdar. Alıç, Fulya. (2013). Dünyanın Kahveleri, Kahvelerin Dünyası Toplumsal Değişimin Bir Aynası Olarak "Kahvehane"den "Starbucks"a, "Starbucks" tan Da

“Kahve Dünyası”na Geçiş. Akademik Bakış Dergisi. S 37. ss. 11-15.

Alver, Köksal. (2009). Ütopya: Mekân ve Kentin İdeal Formu. Sosyoloji Dergisi, 3. Dizi, 18. Sayı, 2009/1, ss. 139-153.

Anlı, Ceyda Kurtar. Nuri, Yavan (2019). Deneyim Yaratmada Mekânın Rolü: Starbucks ve Kahve Dünyası'nın Deneyim Ekonomisi ve Üçüncü Yer Bakımından Analizi. Gaziantep Üniversitesi Sosyal Bilimler Dergisi, Cilt 18, Sayı 1, ss. 100-132.

Atalay, Besim. (1999). Divanü Lûgat-it Türk Tercümesi. C. I, Türk Dil Kurumu Yayınları Ankara. 
Aytaç, Ömer. (2005). Türkiye Kentleşmesinde Bir Ara Kurum: Kent Kahvehaneleri. Sosyal Bilimler Dergisi, 2005/2, ss.179-200.

Aytaç, Ömer. (2007). Kent Mekânlarının Sosyo-Kültürel Coğrafyası. Fırat Üniversitesi Sosyal Bilimler Dergisi, Cilt: 17, Say1: 2, ss.199-226.

Bal, Hüseyin. (2006). Kent Sosyolojisi. Fakülte Kitabevi, Isparta.

Balc1, Fatih. (2019). Cezveden Kültüre 40 Yıl: Türk Kahvesi ve Geleneği. Akademik Sosyal Araştırmalar Dergisi, Yıl: 7, Sayı: 87, Ocak, ss. 315-328.

Baudrillard, Jean. (2013). Tüketim Toplumu. (Çev. Hazal Deliceçaylı, Ferda Keskin), Ayrıntı Yayınları, İstanbul.

Bayat Fuzuli. (2006). Ana Hatlarıyla Türk Şamanlığı, Ötüken, İstanbul.

Bayat, Fuzuli. (2004). Irk Bitig'de Sosyal ve Mitolojik Konular. Folkor/Edebiyat, C. 10, S. 38 , ss. $109-149$.

Bayat, Fuzuli, (1020). Türk Kültüründe Kadın Şaman. Ötüken, İstanbul.

Bilge, Esra. (2010). Evliya Çelebi'den Hareketle Kahvehanelerden Cafelere Dönüşüm. Gazi Üniversitesi Sosyal Bilimler Enstitüsü Türk Halkbilimi Anabilim Dalı, Yüksek Lisans Tezi, Ankara.

Bocock, Robert. (1997). Tüketim. Dost Kitabevi Yayınları, Ankara.

Bookchin, Morrey, (1999). Kentsiz Kentleşme. Ayrıntı Yayınları, İstanbul.

Boratav, P. Naili. (1994). 100 Soruda Türk Folkloru. Gerçek Yayınevi, İstanbul.

Bulduk Sıdıka, Süren, Tufan. (2008). Türk Mutfak Kültüründe Kahve. 38. Icanas Uluslararası Asya ve Kuzey Afrika Çalışmaları Kongresi Bildirileri, Atatürk Kültür, Dil ve Tarih Yüksek Kurumu Yayınları: C 1, Ankara.

Büyükokutan, Aslı. (2012). Muğla' daki Kahve Falına Bakma Geleneği Üzerine Bir Değerlendirme. Folklor/Edebiyat, Cilt:18, Sayı: 71,3, ss. 97-112.

Caferoğlu, Ahmet. (1968). Eski Uygur Türkçesi Sözlüğü. TDK Yayınları, Edebiyat Fakültesi Basımevi, İstanbul.

Çağlayan, Savaş. (2012). Anadolu'nun İlk Kamusal Mekânı: Kahvehane. Muğla Sitkı Koçman Üniversitesi, Sosyal Bilimler Enstitüsü Dergisi, Güz 2012 Sayı 29, ss. 95 110.

Çobanoğlu, Özkul. (2000). Âşık Tarzı Şiir Geleneği ve Destan Türü. Akçağ Yayınları, Ankara.

Çobanoğlu, Özkul. (2003). Türk Halk Kültüründe Memoratlar ve Halk İnançtan. Akçağ Yayınları, Ankara.

Çobanoğlu, Özkul. (2005). Halkbilimi Kuram ve Yöntemleri Tarihine Giriş. 3. Baskı. Akçağ Yayınları, Ankara. 
Demren, Çağdaş. (2007). Kahvehane Erkekliği: Ankara'da Bir Gecekondu Mahallesi Örneği. Hacettepe Üniversitesi Sosyal Bilimler Enstitüsü Antropoloji Anabilim Dalı, Doktora Tezi. Ankara.

Dundes, Alan. (1998). "Halk Kimdir?" (Who Are the Folk?)’ (Çev. Metin Ekici), Milli Folklor, S. 31, ss. 139-157.

Ediz, İsmail. (2008). Osmanlı'dan Cumhuriyet'in İlk Yillarına Kahvehaneler ve Sosyal Değişim. Sakarya Üniversitesi Fen Edebiyat Dergisi 10 (8), ss. 179-189.

Ekici, Metin. (2000). Halk, Halk Bilimi ve Halk Bilgisi Üzerine Bir Deneme. Milli Folklor, S.45, ss. 2-8.

Ersoy, Ruhi. (2012). Halk Bilimi Çalışmalarının Gelişimine Paralel Olarak “Alan Araştırması" Kavramını Yeniden Düşünmek. Millî Folklor, Y11 24, Sayı 94, ss. 513.

Ertürk, Mustafa. (2013). Mekânın Diyalojisi, Kent Mekânı-Kent Öznesi. İstanbul Bilgi Üniversitesi Sosyal Bilimler Enstitüsü. Yayınlanmamış Yüksek Lisans Tezi.

Gömeç, Sadettin Yağmur. (2019). Türklerde Töz, Fal ve Yadacılığga Dair Bazı Tespitler. USAD, Güz (11): 37-62.

Gültekin Mustafa, (2014). Türk Kültüründe Fal ve Falcılık Bağlamında Manisa Selendi Yöresi Irkçıları ve Irk Ocakları. İstanbul Üniversitesi Türk Dili ve Edebiyatı Dergisi, C. 49, S. 49, ss.119-137.

Groh, M. Jennifer. (2016). Mekân Yaratmak. (Çev. Gürol Koca), Metis Yayınları, İstanbul.

Halıc1, Gülşah. (2018). Popüler Kültürün Ekonomik Bir Olgusu: Fal. Karadeniz Araştırmaları, XV/58, Yaz 2018, ss.146-159.

Harvey, David. (2013). Asi Şehirler. (Çev. Ayşe Deniz Temiz), Metis Yayınları, İstanbul.

Harvey, David. (2016). Kent Deneyimi. (Çev. Esin Soğancılar), Sel Yayıncılık, İstanbul.

Hattox, Ralph, S. (1996). Kahve ve Kahvehaneler. (Çev. Nurettin Elhüseyni). Tarih Vakf1 Yurt Yayınları, İstanbul.

Holton, R. J. (1999). Kentler, Kapitalizm ve Uygarlık. (Çev. Ruşen Keleş), İmge Kitabevi, İstanbul.

Hymes, Dell. (1974). Foundation in Sociolingouistics. Universtiy of Pennsylvenia Press, Inc.

İnan, Abdulkadir. (1989). Tarihte ve Bugün Şamanizm. TDK. Yayınları, Ankara.

İslamoğlu, Gözde. Binark Mutlu. (2012). Ankara'da Fal Kafelerde Kahve Falı Bakma/Okuma Edimi. Türk Kahvesi Kitabı. (Ed. Emine Görsoy Nasralı), Kitabevi, İstanbul. 
Kaplan, Melike. (2011). Bir Fincan Keyif, Kahvenin Öyküsü. Yurt ve Dünya Dergisi, 11-20.

Kıray, Mübecel B. (1998). Kentleşme Yazıları, Bağlam Yayıncılık İstanbul.

Koca, Nusret. Tüğen Ersöz Arzu. (2020). Somut Olmayan Kültür Miras Listesinde Bir Değer Olan Türk Kahvesine Coğrafya Perspektifinden Bakış. Troyacademy 5 (1), ss. 347-362.

Kömeçoğlu, Uğur. (2010). “Homo Ludens ve Homo Sapiens Arasında Kamusallık Ve Toplumsallık", Osmanlı Kahvehaneleri. (Ed. Ahmet Yaşar). Kitap Yayınevi, İstanbul.

Lefebvre, Henri. (2014) Mekânın Üretimi. (Çev. Işık Ergüden), Sel Yayıncılık, İstanbul. Malinowski, Bronislaw. (1990). Büyü, Bilim ve Din. Kabalcı Yayınevi, İstanbul.

Morley, David. Robins, Kevin. (1997). Kimlik Mekânları, Küresel Medya, Elektronik Ortamlar veKültürel Sınıralar. Ayrıntı Yayınları, İstanbul.

Miller, Geoffrey. (2012). Tüketimin Evrimi. (Çev. Gülçin Vardar), Alfa, İstanbul.

Nar, Mehmet Şükrü. (2014). Psiko-Antropolojik Bir Olgu Olarak Fal Üzerine Nitel Bir Araştırma. Ankara Üniversitesi Dil ve Tarih-Coğrafya Fakültesi Dergisi 54, 1, ss. 507-524.

Nora Pierre. (2006). Hafıza Mekânları. (Çev. Mehmet Emin Özcan). Dost Kitabevi, Ankara.

Oğuz, M. Öcal. (2007). Folklor ve Kültürel Mekân. Milli Folklor, Y1l 19, Sayı 76, ss. 31 33.

Öncül, Kürşat. (2010). Kültürel Süreklilik ve Kut Taşıyıcılığı. Turkish Studies, Yeni Türk Edebiyatının Kaynakları II, 5(2), ss.1287-1295.

Örnek, Sedat Veyis. (1998). 100 Soruda İlkellerde Din, Büyü, Sanat, Efsane. Gerçek Yayınevi, İstanbul.

Özdemir, Nebi. (2005). Türk Eğlence Kültürü. Akçă̆ Yayınları, Ankara.

Özdemir, Nebi. (2012). Kültür Ekonomisi ve Yönetimi (Seçki). Hacettepe Yayıncılık, Ankara.

Özkoçak, A. Selma. (2010). “Kamusal Alanın Üretim Sürecinde Erken Modern İstanbul Kahvehaneleri", Osmanlı Kahvehaneleri. (Ed. Ahmet Yaşar). Kitap Yayınevi, İstanbul.

Roux, Jean-Paul. (1994). Türklerin Ve Moğolların Eski Dini (Çev. Aykut Kazancıgil). İşaret Yayınları, İstanbul.

Sennett, Richard. (2011). Yeni Kapitalizmin Kültürü. (Çev. Aylin Onocak), Ayrıntı Yayınları, İstanbul.

Sezer, Sennur. (1998). Osmanlı'da Fal ve Falnameler. Ad Kitapçılık, İstanbul. 
Simmel, Georg. (2009). Bireysellik ve Kültür. (Çev. Tuncay Birkan). Metis Yayınları, İstanbul.

Urry, John. (1999) Mekânı Tüketmek. (Çev. Rahmi G. Öğdül), Ayrıntı Yayınları, İstanbul.

Taştan, Yahya Kemal. (2009). Sûfi Şarabından Kapitalist Metaya Kahvenin Öyküsü. Akademik Bakış, Cilt 2, Sayı 4 (Yaz), ss. 53-86.

Tekin, Talat. (2013). Irk Bitig, Eski Uygurca Fal Kitabı. (Yayıma Hazırlayanlar: Emine Yılmaz, Nurettin Demir), TDK. Ankara.

Tutal, Osman. (2014). Kırk Yıllık Hatırın İletişim Mekânı Olarak Kahvehaneler. Anadolu Üniversitesi Sosyal Bilimler Dergisi, C. 14, S. 3, ss. 151-166.

Yaşar, Ahmet. (2005). Osmanlı Şehir Mekânları: Kahvehane Literatürü. Türkiye Araştırmaları Literatür Dergisi, Cilt 3, Sayı 6, ss. 237-256.

Yokarı, Funda. (2014). Konuşmanın Etnografyası Bağlamında Falcılık Geleneği, Hacettepe Üniversitesi Sosyal Bilimler Enstitüsü Türk Halkbilimi Anabilim Dalı, Yüksek Lisans Tezi, Ankara.

\section{Kaynak Kişi Listesi}

KK1. Nesrin Ceylan Uzel, 46 yaşında, Gaziantep, Lise.

KK2. Baybars Bilim, 23 yaşında, Afyon, Üniversite.

KK3. Şaziye Emir/ 44, yaşında, Gaziantep, İlkokul.

KK4. Ferhan H. 47 yaşında, Gaziantep, Üniversite.

KK5. Faruk Gören, 39 yaşında, Denizli, Lise.

KK6. Müjgan H. 52, yaşında, İran-Tahran, Üniversite.

KK7. Gülşen Şen, 27 yaşında, Şırnak, Üniversite.

KK8. Aybüke Yümlü, 37 yaşında, Kahramanmaraş, Üniversite.

KK9. C. P. 24 yaşında, Adana, Üniversite.

KK10. Erdi Özçelik, 31 yaşında, Mersin, Lise.

KK11. Mehmet Vehbi Cirit, 34 yaşında, Mersin, Lise. 